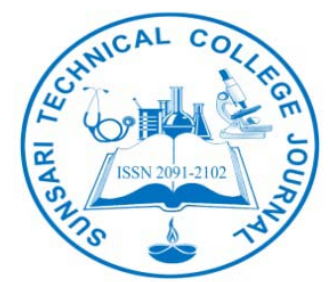

\title{
EVALUATION OF MICROBIOLOGICAL QUALITY OF INDIGENOUS DAHI FROM EASTERN NEPAL
}

\author{
Rewati Raman Bhattarai ${ }^{*}$, Suman Kumar Lal Das ${ }^{1}$ \\ ${ }^{1}$ Tribhuvan University, Institute of Science and Technology, Central Campus of Technology, Hattisar, Dharan, Nepal. \\ *Corresponding author email: noble_rewinem1@yahoo.com
}

Received: 7.08.2014; Revised and Accepted- 12.11.2014

DOI: http://dx.doi.org/10.3126/stcj.v2i1.14793

\begin{abstract}
The present study was undertaken to evaluate the microbiological quality of indigenous dahi from eastern Nepal. A total of 39 indigenous dahi samples were collected from sixteen districts of eastern Nepal and analyzed. Results revealed the mean yeasts and mould count to be $20.5 \times 10^{4} \pm 7503$, coliform count $65 \pm 42$, S. aureus $197 \pm 65$ and total viable bacterial count $227 \times 10^{6} \pm 17250$ cfu/g. Total viable bacteria and yeasts and moulds were present in all samples examined. Coliforms were present in $90 \%$ and $S$. aureus were present in $63 \%$ of samples examined whereas salmonella species were not detected in any of the samples under study.
\end{abstract}

Keywords: Indigenous dahi, evaluation, microbial count, food safety, Nepal.

\section{INTRODUCTION}

Fermentation has been regarded as the oldest food biotechnological process used to prolong the shelf life of milk by converting it into different products ${ }^{1}$. Of them, dahi is one of the most popular traditional fermented milk products of the Himalayas ${ }^{2}$. It is obtained from pasteurized or boiled milk by souring with natural microflora or by harmless lactics or other bacterial culture ${ }^{3,4}$. Dahi is highly nutritious and more digestible than milk ${ }^{5}$ and recognized as healthy food product. Nutritionally, it contains higher amount of vitamins, minerals, whey proteins and bioactive lipid components but lower amount of lactose than milk ${ }^{6}$.The therapeutic properties of dahi is well known fact and has been extensively documented by Lalayeet al. ${ }^{7}$; Yadavet $a{ }^{8}{ }^{8}$; Arvindet al. ${ }^{9}$; Abdel-Salam ${ }^{10}$; Gandhi and Natrajan $^{11}$; Bhat and Bhat ${ }^{12}$; Rahmanet al. ${ }^{13}$; Bhattarai $^{14}$; Bhattarai and Das $^{4}$ and Bhattarai and Timilsina ${ }^{6}$. Owing to its chemical, microbiological and nutritionalcomponents, it is preferred as a source of probiotic ${ }^{6}$. Most importantly and since time immemorial, it has been used in curing gastrointestinal disorders like constipation, diarrhea, dysentery, etc. ${ }^{15,16,11,4,6}$. The microorganisms in dahi fermentation include mixed strains of lactic acid bacteria and lactose fermenting yeasts ${ }^{17,18,4}$. Since the use of standard culture and method is not practiced while making $d a h i^{19}$, the quality of dahi may varies with the type of starter culture used ${ }^{20}$ and manufacturing techniques by different manufacturers ${ }^{4}$. The important factors associated with low quality dahi production are the use of poor quality milk and unhygienic practices during preparation, handling, storage and transportation. In addition, loose packing further deteriorates keeping quality of $d a h i^{21,22}$ which consequently results in growth of unwanted microorganisms. Many pathogenic microorganisms were isolated from traditionally fermented dairy products of different parts of the world. These organisms are S. aureus, B. cereus, Klebsiella and coliforms $^{23,24,25}$. In the light of the above stated fact, the present study has been undertaken to evaluate the microbiological quality of indigenous dahi available in eastern Nepal.

\section{MATERIAL AND METHODS}

Collection of Samples: A total of 39 indigenous dahi samples were collected from sixteen districts of eastern Nepal during September-November 2012.Thesamples were collected insterile screw capped test tubes and kept cool in ice-boxuntil taken to the laboratory where they were kept at $<4^{\circ} \mathrm{C}$ for further use.

Isolation and enumeration of microbes: The determination of microbial counts was done according to $\mathrm{APHA}^{26}$.One gram of 
sample was homogenized with $9 \mathrm{~mL}$ Quarter Strength Ringer's Solution to make an initial dilution $\left(10^{-1}\right)$. Serial dilutions of the suspended samples were performed and $0.1 \mathrm{~mL}$ aliquots of the appropriate dilution $\left(10^{-3}, 10^{-4}\right.$, and $\left.10^{-5}\right)$ spread plated in duplicate on

i. Potato dextrose agar medium was used for the enumeration of yeasts and moulds and plates were incubated at $30^{\circ} \mathrm{C}$ for 5 days.

ii. Violet Red Bile Agar (VRBA) medium was used for the numeration of coliform bacteria and the plates were incubated at $32^{\circ} \mathrm{C}$ for $24 \mathrm{~h}$.

iii. Salmonella Shigella agar medium was used for detection of Salmonella sp. and incubated at $35^{\circ} \mathrm{C}$ for $48 \mathrm{~h}$.

iv. Mannitol salt agar medium was used for the enumeration of $S$. aureus and the plates were incubated at $37^{\circ} \mathrm{C}$ for 48 h.

v. Plate count agar was used for the enumeration of total viable bacteria, and the plates were incubated at $32^{\circ} \mathrm{C}$ for $48 \mathrm{~h}$.

\section{RESULTS}

The counts of different organisms are shown in Table 1. Results presented in Table 1 revealed that the total yeast and mold count ranged from $0.5 \times 10^{3}$ to $35 \times 10^{5} \mathrm{cfu} / \mathrm{g}$, with mean count of $20.5 \times 10^{4} \pm 7503$. Likewise, coliform count ranged from $0.5 \times 10^{1}$ to $0.27 \times 10^{3} \mathrm{cfu} / \mathrm{g}$, with mean count of $65 \pm 42$. The salmonella organism was not detected in all samples collected from all districts under study whereas $S$. aureus was in the range of 53 to $315 \mathrm{cfu} / \mathrm{g}$, with mean count of $197 \pm 65$. The total viable bacteria count ranged from $225 \times 10^{6}$ to $228 \times 10^{6} \mathrm{cfu} / \mathrm{g}$, with mean count of $227 \times 10^{6} \pm 17250$ in the present study.

Table 1: Counts of different organisms

\begin{tabular}{|lllll|}
\hline & $\begin{array}{c}\text { Yeasts } \\
\text { and } \\
\text { Moulds }\end{array}$ & Coliforms & aureus & TVC \\
\hline Minimum $^{*}$ & $0.5 \times 10^{3}$ & $0.5 \times 10^{1}$ & 53 & $225 \times 10^{6}$ \\
Maximum $^{*}$ & $35 \times 10^{5}$ & $0.27 \times 10^{3}$ & 315 & $228 \times 10^{6}$ \\
Mean & $20.5 \times 10^{4}$ & 65 & 197 & $227 \times 10^{6}$ \\
SD & 7503 & 42 & 65 & 17250 \\
\hline
\end{tabular}

*The counts are mean of triplicate of thirty nine samples.

The mean and SD values are mean of all thirty nine samples.

\section{DISCUSSION}

Yeasts and moulds count: Yeasts and moulds were present in all samples examined. Nearly similar results were previously reported by Lore et al. ${ }^{24}$; Al-Otaibi et al. ${ }^{27}$; Sun et al. ${ }^{28}$; Dey et al. ${ }^{29}$. Lower results were reported by Fleet and $\mathrm{Mian}^{30}$ and El-Malt et al. ${ }^{31}$. However, somewhat higher results were recorded in similar studies $32-40,25,41-44$. The present result is above the standard set by BIS for yeasts and molds of not greater than $10 \mathrm{cfu} / \mathrm{g}$. Traditional practices and unhygienic conditions might have resulted higher values in present study. Ghosh et al. ${ }^{43}$ in their study reported that the higher counts of yeasts and moulds in dahi above the standard might be because these organisms can grow at a low $\mathrm{pH}$ and in low water activity $\left(\mathrm{a}_{\mathrm{w}}\right)$ created by high sugar concentration. Abdalla and Hussain $^{44}$ and Dey et al. ${ }^{29}$ focused on poor processing conditions and/or uncontrolled fermentation for contamination with yeasts and moulds. According to Abdel All and Dardir ${ }^{42}$ and El-Malt et $a l .{ }^{31}$, the presence of yeasts and molds indicates poor sanitary conditions during preparation, packaging or transportation.

Coliform bacteria count: The present result is above the standard set by BIS for coliforms of not greater than $10 \mathrm{cfu} / \mathrm{g}$. Coliforms were present in $90 \%$ of samples examined in present study. Despite heating milk for longer periods in traditional methods of dahi making in Nepal, such higher coliform values might be due to post processing contamination. Nearly similar results were reported in similar studies ${ }^{24,27}$. However higher results were found in other similar studies 45,33, 25, 42 . Abdel All and Dardir ${ }^{42}$ stated that coliforms count might be a consequence of the low level of hygiene maintained during processing. This includes the handlers, quality of water used and the utensils. El-Malt et al. ${ }^{31}$ reported coliforms as an indication of post processing contamination.

Salmonella sp.: The present result did not detect any salmonella species. Similar results were recorded in similar studies $23,46,47,42$, ${ }^{43}$. This might be due to growth of other micro-organisms which suppressed the growth of salmonella species.

S. aureuscount:S. aureus in this study were present in $63 \%$ of samples examined. Nearly similar results were reported in similar studies ${ }^{47}$ but higher results reported in other studies 42,31 . According to El-Malt et al. ${ }^{31}$, presence of $S$. aureus indicates contamination from food handlers through hand or arm lesions caused by $S$. aureus or by coughing and sneezing which is common during respiratory infections or in symptomatic carriers that come in contact with food. As reported by Abdel All and Dardir $^{42}$, the presence of staphylococci in high count is a potential health hazard if toxin producing strains are present.

Total viable bacteria count (TVC): The mean TVC in this study was $227 \times 10^{6} \pm 17250 \mathrm{cfu} / \mathrm{g}$. Abdalla and Hussain ${ }^{43}$ reported similar values of TVC $\left(33 \times 10^{6}\right.$ to $\left.295 \times 10^{6} \mathrm{cfu} / \mathrm{mL}\right)$ whereas Dey et al. ${ }^{29}$ reported lower values $\left(7 \times 10^{5}\right.$ to $\left.8 \times 10^{5}\right)$ in their studies. The possibility for such variations might be due to the use of undefined wild starter culture in improper ratio and amount. It also contains heterogeneous mixture of lactic acid bacteria; as a result TVC in dahisamples varies ${ }^{29}$.

\section{CONCLUSION}

The initial high levels of contamination with bacteria, yeasts and moulds are undesirable and it has resulted in dahi of inferior quality. Presences of these organisms are critical for the safety of fermented milk. Minimizing contamination of milk is therefore recommended for controlling pathogen levels in dahi. Measures should be taken to interrupt the transmission of pathogens to dahi at the household level. This could be achieved by applying Good Manufacturing Practices (GMP), Good Hygienic Practices (GHP) and educating food handlers particularly mothers.

\section{ACKNOWLEDGEMENT}


We are grateful to all the staffs and faculty of food technology, central campus of technology, Dharan for their support and encouragement during the study.

\section{REFERENCES}

1. Tamime AY and Robinson RK. Yoghurt Science and Technology, 2nd (ed) CRC Press, Boca Raton F. L. New York., 1999.

2. Tamang JP. Himalayan Fermented Foods Microbiology, Nutrition, and Ethnic Values. CRC Press, Taylor \& Francis Group, 2010.

3. Kharel GP, Acharya PP and Rai BK. Traditional Foods of Nepal. Highland Publications, Kathmandu, Nepal, 2010.

4. Bhattarai RR and Lal Das SK. Scientific Study on Indigenous Technology of Dahi Making of Eastern Nepal. Journal of Food Processing \& Technology, 2013; 4: 253.

5. Durga LC, Sharda D and Sastry MP. Effect of storage conditions on keeping quality, .riboflavin and niacin of plain and fruit yoghurt. Indian Journal of Dairy Science, 1986; 39: 404409.

6. Bhattarai RR and Timilsina, YP. Fermented milk dahi. Food wave,10, 2013; pp. 51-59.

7. Laleye SA, Igbakin AP and Akinyanju JA. Antidiabetic effect of Nono(a Nigerian fermented milk) on alloxan-induced rats. American Journal of Food Technolology, 2008; 3: 394-98. http://dx.doi.org/10.3923/ajft.2008.394.398

8. Yadav H, Jain S and Sinha PR. Oral administration of dahi containing probiotic Lactobacillus acidophilus and Lactobacillus casei delayed the progression of streptozotocin-induced diabetes in rats. Journal of Dairy Research, 2008; 75:189-95. http://dx.doi.org/10.1017/S0022029908003129

9. Arvind, Sinha PR, Singh NK, Kumar R. Effect of Acidophiluscaseidahi (Probiotic curd) on lipids in 1, 2 dimethylhydrazine induced intestinal cancer in rats. International Journal of Probiotics and Prebiotics 2009; 4:195-200.

10. Abdel-Salam AM. Functional foods: hopefulness to good health. American Journal of Food Technology 2010; 5: 86-99. http://dx.doi.org/10.3923/ajft.2010.86.99

11 Gandhi DN and Natrajan AM. Preparation of a Good Quality Dahi (Curd) and Probiotic Milk Products, 2010. Available in http://karnaldirectory.com/wp-content/uploads/2010/06/DahiMaking.pdf

12. Bhat ZF and Bhat H. Milk and dairy products as functional foods - a review. International Journal of Dairy Science, 2011; 6:1-12. http://dx.doi.org/10.3923/ijds.2011.1.12

13. Rahman MN, ObidulHuq AK, GolamMoktadir SM. and Akter MM. Quality Assessment of Sweet Curds (MistiDahi) from Two Selected Areas of Bangladesh. Research \& Review: Journal of Dairy Science and Technology, 2012; 1(1): 32-38.
14. Bhattarai RR. Study on technology and microbiology of dahi: an indigenous dairy product from eastern Nepal. Unpublished M. Tech. Dissertation. Trivuwan Univ., Nepal, 2013.

15. Gandhi DN and Nambudripad VKN. Implantation of Lactobacillus acidophilus in the intestine of adult suffering from gastrointestinal disorders. Indian Journal of Dairy Science, 1975; 28: 72.

16. Athar IH. Preparation of Cheese and Yoghurt (Dahi) at Household Level. Pakistan Agricultural Research Council, Islamabad, 1986.

18. Steinkraus KS. Handbook of indigenous fermented foods. Marcel Dekker, Inc. New York, 1996.

19. Tamang JP. andDewan S. Dominant lactic acid bacteria and their technological properties isolated from the Himalayan ethnic fermented milk products. Antonie van Leeuwenhoek, 2007; 92: 343-352. http://dx.doi.org/10.1007/s10482-007-9163-5

20. Masud T, Sultana K and Shah MA. Incidence of lactic acid bacteria isolated from indigenous Dahi. Australian Journal of Animal Science, 1991; 4: 329-331. http://dx.doi.org/10.5713/ajas.1991.329

21. Aziz T. Thermal processing of Dahi to improve its keeping quality. Indian Journal of Nutrition and Dietetitics, 1986; 22: 8087.

22. Sarkar MM, Nahar TN, Alam MK, Rahman MM, Rashid MH and Islam MA. Chemical and bacteriological quality of popular Dahi available in some selected areas of Bangladesh. Bangladesh Journal of Animal Science, 2012; 41 (1): 47-51. http://dx.doi.org/10.3329/bjas.v41i1.11977

23. Beukes EM, Bernie HB and Johannes FM. The microbiology of South African traditional fermented milks. International Journal of Food Microbiology, 2001; 63: 189-197. http://dx.doi.org/10.1016/S0168-1605(00)00417-7

24. Lore AT, Mbugua KS and Wango HJ. Enumeration and identification of microflora in suusac, a Kenyan traditional fermented camel milk product. Lebensm- Wiss.u.- Technology, 2005; 38: 125-130.

25. Uzeh R, Ohenhen R and Rojugbokan A. Microbiological and Nutritional Qualities of Dairy Products: Nono and Wara. Nature and Science, 2006; 4: 37-41.

26. APHA. American Public Health Association, 1992. Standard Methods for the Examination of Dairy Products. 16th edition. Washington, DC. 1992.

27. Al-Otaibi MM. Evaluation of some probiotic fermented milk products from Al-Ahsa markets, Saudi Arabia. American Journal of Food Technology 2009; 4:1-8. http://dx.doi.org/10.3923/ajft.2009.1.8

28 Sun T-S, Bai M, Qing M, Guo Z, Chen YZX, Bao Q and Zhang $\mathrm{H}$. Occurrence and dominance of yeast species in naturally fermented milk from the Tibetan Plateau of China. Canadian Journal of Microbiology, 2010; 56: 707-714. 
http://dx.doi.org/10.1139/W10-056

29. Dey S, Iqbal A, Ara A and Rashid MH. Evaluation of the quality of Dahi available in Sylhet Metropolitan City. Journal of Bangladesh Agricultural University, 2011; 9(1): 79-83 http://dx.doi.org/10.3329/jbau.v9i1.8748

30. Fleet GH and Mian MA. The occurrence and growth of yeasts in dairy products. International Journal of Food Microbiology, 1987; 4 (2): 145-155.

http://dx.doi.org/10.1016/0168-1605(87)90021-3

31. El-Malt LM, Abdel HKG and Mohammed AS.

Microbiological evaluation of yoghurt products in Qena city, Egypt. Veterinary World, 2013; 6(7): 400-404.

http://dx.doi.org/10.5455/vetworld.2013.400-404

32. Atanda $\mathrm{OO}$ and Ikenebomeh MJ. Microbiological quality of nono. World Journal of Microbiology and Biotechnology, 1991; 7: 89-91. http://dx.doi.org/10.1007/BF02310922

33. Adebesin AA, Amusa NA and Fadage SO. Microbiological quality of locally fermented milk (nono) and fermented milk cereal mixture (Fura da nono) drink in Bauchi, a Nigerian city. Journal of Food Technology 2001; 6: 87-89.

http://dx.doi.org/10.4314/jfta.v6i3.19295

34. Guizani N, Kasapis S and Al-Ruzeiki M. Microbial, chemical and rheological properties of laban (cultured milk). International Journal of Food Science and Technology, 2001; 36: 199-205. http://dx.doi.org/10.1111/j.1365-2621.2001.00451_36_2.x

35. Olasupo NA, Smith SI and Akinsinde KA. Examination of the microbial status of selected indigenous fermented foods in Nigeria. Journal of FoodSafety, 2002; 22: 85-93. http://dx.doi.org/10.1111/j.1745-4565.2002.tb00332.x

36. Savadogo A, Ouattara T, Savadogo P, Ouattara A, Barro N and Traore A. Microorganisms Involved in Fulani Traditional Fermented Milk in Burkina Faso. Pakistan Journal of Nutrition, 2004; 3: 134-139. http://dx.doi.org/10.3923/pjn.2004.134.139

37. Rashid M and Miyamoto T. Quality Evaluation of Traditional Fermented Milk "Dahi" in Bangladesh. Journal of Milk Science, 2005; 54(1): 29-36.

38. Obodai M and Dodd C. Characterization of dominant microbiota of Ghanaian fermented milk products, nyarmie, by culture and non-culture-based methods. Journal of Applied Microbiology, 2005; 100: 1355-1363. http://dx.doi.org/10.1111/j.1365-2672.2006.02895.x

39. Sulieman AM, Ilayan AA and El-Faki AE. Chemical and microbiological quality of Garris, Sudanese fermented camel's milk product. International Journal of Food Science and Technology, 2006; 41: 321-328.

http://dx.doi.org/10.1111/j.1365-2621.2005.01070.x

40.Shuangquan, Burentegusi, Bai Y. and Miyamoto T. Microflora in traditional starter cultures for fermented milk, hurunge, from inner Mongolia, China. Journal of Animal Science, 2006; 77: 235-241.

http://dx.doi.org/10.1111/j.1740-0929.2006.00343.x
41. Hassan RA, El Zubeir IE and Babiker SA. Chemical and Microbial Measurements of Fermented Camel Milk "Gariss" from Transhumance and Nomadic Herds in Sudan. Australian Journal of Basic and Applied Science, 2008; 2: 800-804.

42. Abdel All AAA, and Dardir HA. Hygienic Quality of Local Traditional Fermented Skimmed Milk (Laban Rayb) Sold in Egypt. World Journal of Dairy \& Food Sciences 2009; 4 (2): 205209.

43. Ghosh JS, Kumbhar SB and Samudre SP. Occurrence of Disease Causing Organisms Including Bacteriophages in Indigenous Fermented Milk Products. Advances in Journal of Food Science and Technology, 2010; 2 (4): 196-199.

44. AbdallaMOM, and Hussain SIK. Enumeration and Identification of Microflora in Roub, A Sudanese Traditional Fermented Dairy Product. British Journal of Dairy Science 2010; 1(2): 30-33.

45. Al-Shaikhli JS. A study of fermented milks in the Riyadh area, Incidence of coliform contamination. Abstract only; Conference paper, Fourth Symposium on the biological aspects of Saudi Arabia, held at the University of Riyad, Saudi Arabia, 1980; pp. 68.

46. Nassib TA, El-Din MZ and El-Sharoud WM. Assessment of the presence of Salmonella spp. in Egyptian dairy products using various detection media. Letters in Applied Microbiology, 2003; 37: 405-409.http://dx.doi.org/10.1046/j.1472-765X.2003.01420.x

47. Varga L. Microbiological quality of commercial dairy products. Communicating Current Research and Educational Topics and Trends in Applied Microbiology, 2007; pp: 487-494.

Cite this article as: Bhattarai RR, Das SKL.Evaluation of microbiological quality of indigenous dahi from eastern Nepal .STCJ 2015;2(1):23-26. 